\title{
University Library Websites in Nigeria: An Analysis of Content
}

\author{
Abubakar Mohammed ${ }^{1 *}$, Aminu Garba ${ }^{2}$, Hafiz Umar $^{3}$ \\ 1.Department of Library and Information Science Ahmadu Bello University (ABU), Zaria. Kaduna State Nigeria \\ Email: amkareto@gmail.com \\ 2.Dr. M A Kazaure Digital Library Hussaini Adamu Federal Polytechnic Kazaure Jigawa State, Nigeria \\ Email: aminu33@yahoo.com \\ 3.Polytechnic Library, Federal Polytechnic Bali, Taraba State, Nigeria Email: uafeeth@yahoo.com \\ *E-mail of the corresponding author: amkareto@gmail.com
}

\begin{abstract}
The Internet and web technologies created a new and unprecedented environment to governments, businesses, educational institutions, and individuals enabling them to webcast any information using multimedia tools. University libraries are nowadays using web environment to provide high quality information for their users mostly in digital format. The purpose of this study is to investigate the university library websites in Nigeria, to analyse their content so as to ascertain their strength and weaknesses and to give recommendations. Three objectives guided the study. Ten university libraries with functional websites were randomly selected for the study. Fourty three (43) item checklists were developed based on previous studies and critical extermination of standard library websites. The checklists were scanned and analyse in various intervals during the month of December 2013, the results are presented in tabular form. The study found among others that the general information about the selected libraries, about library services, about their physical holdings are all inadequate. Recommendations made include improvement of librarian skills in website development and enhancement of library curriculum in library schools to include website development among others.
\end{abstract}

Keywords: University library, Websites, Content analysis, Nigeria

\section{Introduction}

The academic libraries in Nigeria, in particular the University Libraries of today, are improving their service base with the application of Information technology to facilitate access and delivery of e-content to their ever growing technology savvy clients. In this process they are also adapting to the change, altering their image, by executing new functions and providing varieties of services in an evolving continuum. The rapid developments in information technologies have already laid a solid foundation for a new innovative evolution of university in the ongoing digital era across the globe. Impacted by new advances in emerging and cutting-edge technologies, however, "academic libraries have already transformed their specific functions in today's changing world as; information center, learning center, training center, publication center" (Lilili, 2009).

The World Wide Web (WWW), the invention of Tim Barnes Lee, has also created tremendous influence in the transformation of libraries as knowledge resource centres, rather than store house of print media. The impact of this change is all pervasive and affecting all the aspects of library operations, information resources and services, staff skills requirements and users expectations. The accelerating pace of technological developments has tremendously increased the ability to access, store, process, communicate and deliver information services to the desk-tops of the libraries' clients. The vast majority of library services are now Web-enabled and so attention is being focused on designing user-friendly and easily managed and maintained library websites. According to Diaz (1998) "a library website can play different roles; it can serve as a workstation where a user finds databases, electronic texts, and the online catalog. It is a way to make library-made products available; it is used as a window to the WWW by making Internet resources available on a selective basis, and it is a communication tool where information about services, people and facilities and collections can be found." The development of library web sites started in the 1990s. As soon as Mosaic, the world's first web browser, was released in 1993 academic health science libraries began developing web sites (Brower, 2004). Similarly, Vaughan (2001) also describes the development of the library web site at the University of Nevada-Las Vegas (UNLV) Libraries, which became operational in 1996. Today, very few university libraries are without a presence on the web. As the number of library websites grew, it was necessary to analyse them.

The researchers observed that there is little research that focuses specifically on the content of university library websites I Nigeria, therefore a need was felt to analyse the content of university library website in Nigeria, which may lead to improvement and the development of other more useful library web sites.

\section{University Libraries and the Paradigm Shift}

The global trend is now characterized with a fundamental shift from traditional information environment to an eenvironment where emphasis is placed more on the acquisition of e-resources such as e-books, e-journals as well as online databases. Today, the contemporary practice in university library services in the 21 st century is being 
propelled with an information explosion, and the inclusion of Information and Communication Technologies (ICTs) in all aspects of library services. Kumar (2009) notes that university libraries are changing dramatically by adopting new means of technology in all activities of print to e-environment where a variety of manual method, are replaced by computerized system which provides opportunity for online accessibility.

University libraries are now expected to provide to users a range of information and communication technologies necessary for retrieving information quickly from both immediate and remote databases, as well as creating a need for library cooperation and consortium initiatives (Okiy, 2005)

The present-day University library services in the 21 st century is focusing more on the area of digital, virtual or libraries without borders all of which have transformed academic libraries and led to transition and transformation in the university library environment. The transition and the transformation are accompanied with sophistication in the changing pattern in the information seeking tactics of technology savvy users. Singh and Kaur (2009) observed that there is a paradigm shift from stand-alone libraries to library and information networks; from printed publications to digital documents; and from ownership to access.

Developments in ICTs have now offered university libraries an exciting and challenging opportunities that requires them to respond positively in all facets of their services and functions if they are to remain relevant in the $21^{\text {st }}$ century. Thus, university libraries must devise means of survival.

\section{Objectives of the Study}

The study objective is to determine the information content on the selected university library Web pages under study, for better accessibility and use. More specifically, the study objectives are:

1. To analyse the contents of the Nigerian university library websites under study

2. To determine the services and facilities provided in university library websites under study

3. To suggest measures for the improvement of Nigerian university library websites under study

\section{Review of Related Literature}

Computerisation of University libraries in Nigeria started in the mid-19s (Akintunde, 2004). At the time of writing this paper (Dec-2013) only a few university libraries in Nigeria have functional websites. The university libraries that have websites are either owned by their parent organisations or by themselves, mostly present incomplete information and have poor content. Even after a decade of web site development, Nigerian University libraries cannot define the needs of websites properly neither have them any guidelines or directory to follow regarding existing practices or problems.

Ward and Mervar (2003) stated that a library's website is a powerful gateway that can provide information to patrons, but often users access Google or other sources for information even though library websites provide more authentic, reliable and organised information and internet sources than the "general" internet. According to Diaz (1998) a library website can, and by default does, play a variety of roles. First, a library website often serves the role of a library workstation, both for the users and for the librarians serving them. This necessitates a presentation and organisation that allows users to know all that the library has to offer electronically, and in a way that makes sense. It is a tool that will help to speed up or slow down the reference librarians' work in assisting patrons to find information. It is a tool that will help or hinder the user in expanding research or in finding the answer to a very simple question, such as how to determine if the library has a particular book and where it might be found. Previous analyses of library web site content have viewed a number of factors related to navigation, access, speed, general library information, mission statements, collection, resources and services, catalogue access, electronic resources, contact information and other interactive services such as RSS feeds, chats with a librarian etc.

Nielsen and Tahir (2002) stated that an institution's homepage is its face to the world, its building's lobby, and the company receptionist. Davis (1989) in discussing perceived usefulness and ease of use of information technology noted that ease in identifying the current location in any online search is an important navigation feature. Frequent updating of website contents is another feature affecting the quality of websites (Huang et al., 1999). Brower (2004) analysed academic health library websites' contents and navigational elements. These elements included general information about the library, library website aids and tools, library services, library resources and navigational metrics through many questions. Michalec (2006) conducted a content analysis of art library websites. He analysed content, contact details, hours of operations, information about the library collections, the library web page location on the parent organisation website, and number of clicks required to navigate library information. He also analysed the availability of search engine links, internet subject resources, local resources, electronic databases, and links to reference assistance along with other basic library-related information contents. Lee (2001) added to this list links to other internet resources, internal electronic database services, external electronic database services, language, instructional support, loading speed and marketing techniques for evaluating the academic library web sites in Malaysia. Overall, a library website serves as a delivery mechanism for databases, electronic texts and journals, and often for the library catalogue. In delivering 
these resources, the web requires a dialogue between users and technical service librarians to determine how and where to represent access to all this information. Experts have seen a revolution in the interaction between these units when OPACs first became available, and this has developed with the need to provide appropriate library web sites. Diaz (1998) observed that the web had allowed librarians to find new roles as information generators, as well as to continue the functions of information gathering, organisation, and access.

\section{Methodology}

In the absence of any directory of university library website in Nigeria, information for this study was collected through searching and browsing the Web. During the process a number of university library websites appeared. Many universities don't have library websites therefore such were not selected for the study, Ten (10) university libraries with functional library websites were randomly chosen for the study. A 2 page checklist containing 43 was developed based on the study conducted by Brower (2004), Qutab (2009), Michalec (2006) and critical examination of few standard university library websites i.e. Massachusetts Institute of Management Technology library website, Manchester Metropolitan University Library website and University of Durham library website. The checklist were scanned and analysed at various time during the month of December 2013, data were also presented in tabular form using MS Word.

Table 1: List and Website Addresses of the University Libraries Studied

\begin{tabular}{|c|c|c|}
\hline $\mathbf{S} / \mathbf{N}$ & University Libraries & Website Addresses \\
\hline 1 & John Harris Library, University of Benin (UNIBEN) & http://library.uniben.edu/ \\
\hline 2 & University of Lagos Library (UNILAG) & http://library.unilag.edu.ng/ \\
\hline 3 & American University of Nigeria Library (AUN) & http://library.aun.edu.ng/ \\
\hline 4 & Kenneth Dike Library, University of Ibadan (UI) & http://library.ui.edu.ng/ \\
\hline 5 & University of Nigeria Nsukka Library (UNN) & http://unn.edu.ng/library \\
\hline 6 & Kashim Ibrahim Library, Ahmadu Bello University Zaria (ABU) & http://abu.edu.ng/library/ \\
\hline 7 & $\begin{array}{l}\text { Donald E. U. Ekong library, University of Port Harcourt } \\
\text { (UNIPORT) }\end{array}$ & http://library.uniport.edu.ng/ \\
\hline 8 & $\begin{array}{l}\text { Festus Agagbo Nwalo Library, Nnamdi Azikiwe University } \\
\text { (UNIZIK) }\end{array}$ & http://www.naulibrary.org/ \\
\hline 9 & $\begin{array}{l}\text { Nimbe Adedipe Library, University of Agriculture Abeokuta } \\
\text { (UNAAB) }\end{array}$ & http://www.library.unaab.edu.ng/ \\
\hline 10 & University of Ilorin Library (UNIILORIN) & http://www.unilorin.edu.ng/unilibrary/ \\
\hline
\end{tabular}

\section{Analysis and Interpretation of Data}

7.1 General Information

The general information about the library includes information about the institution, the library, mission/vision statement, working hours/holidays, membership information, copyright, library committee, library staff, site map/floor map, library sections/divisions, annual reports and statistics, ongoing projects.

Table 2: General Information Available in Library Websites

\begin{tabular}{|c|c|c|c|c|c|c|c|c|c|c|}
\hline General Information & 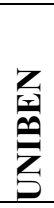 & $\underset{\mathrm{Z}}{\mathrm{Z}}$ & 岁 & 5 & 竞 & $\stackrel{\infty}{2}$ & $\begin{array}{l}\bar{x} \\
\underline{0} \\
\vdots \\
\bar{z}\end{array}$ & $\frac{\underline{N}}{\mathbf{Z}}$ & 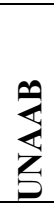 & 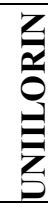 \\
\hline About Institution & $\mathrm{N}$ & $\mathrm{N}$ & $\mathrm{N}$ & $\mathrm{N}$ & $\mathrm{Y}$ & $\mathrm{N}$ & $\mathrm{N}$ & $\mathrm{N}$ & $\mathrm{N}$ & $\mathrm{N}$ \\
\hline About the Library & $\mathrm{Y}$ & $\mathrm{Y}$ & $\mathrm{Y}$ & $\mathrm{Y}$ & $\mathrm{Y}$ & $\mathrm{Y}$ & $\mathrm{Y}$ & $\mathrm{Y}$ & $\mathrm{Y}$ & $\mathrm{Y}$ \\
\hline Mission/Vision Statement & $\mathrm{N}$ & $\mathrm{N}$ & $\mathrm{Y}$ & $\mathrm{N}$ & $\mathrm{Y}$ & $\mathrm{Y}$ & $\mathrm{Y}$ & $\mathrm{Y}$ & $\mathrm{Y}$ & $\mathrm{N}$ \\
\hline Working Hours/Holidays & $\mathrm{Y}$ & $\mathrm{Y}$ & $\mathrm{Y}$ & $\mathrm{Y}$ & $\mathrm{N}$ & $\mathrm{N}$ & $\mathrm{Y}$ & $\mathrm{N}$ & $\mathrm{Y}$ & $\mathrm{N}$ \\
\hline Membership Information & $\mathrm{Y}$ & $\mathrm{Y}$ & $\mathrm{Y}$ & $\mathrm{Y}$ & $\mathrm{N}$ & $\mathrm{Y}$ & $\mathrm{Y}$ & $\mathrm{N}$ & $\mathrm{Y}$ & $\mathrm{N}$ \\
\hline Copyright & $\mathrm{N}$ & $\mathrm{N}$ & $\mathrm{N}$ & $\mathrm{N}$ & $\mathrm{N}$ & $\mathrm{Y}$ & $\mathrm{N}$ & $\mathrm{N}$ & $\mathrm{N}$ & $\mathrm{N}$ \\
\hline Library Committee & $\mathrm{N}$ & $\mathrm{N}$ & $\mathrm{N}$ & $\mathrm{N}$ & $\mathrm{N}$ & $\mathrm{N}$ & $\mathrm{N}$ & $\mathrm{N}$ & $\mathrm{N}$ & $\mathrm{N}$ \\
\hline Library Staff & $\mathrm{N}$ & $\mathrm{N}$ & $\mathrm{N}$ & $\mathrm{Y}$ & $\mathrm{N}$ & $\mathrm{N}$ & $\mathrm{Y}$ & $\mathrm{Y}$ & $\mathrm{Y}$ & $\mathrm{N}$ \\
\hline Site Map/Floor Map & $\mathrm{N}$ & $\mathrm{N}$ & $\mathrm{N}$ & $\mathrm{Y}$ & $\mathrm{N}$ & $\mathrm{N}$ & $\mathrm{N}$ & $\mathrm{N}$ & $\mathrm{Y}$ & $\mathrm{N}$ \\
\hline Library Sections/Divisions & $\mathrm{Y}$ & $\mathrm{Y}$ & $\mathrm{Y}$ & $\mathrm{Y}$ & $\mathrm{Y}$ & $\mathrm{Y}$ & $\mathrm{Y}$ & $\mathrm{Y}$ & $\mathrm{Y}$ & $\mathrm{Y}$ \\
\hline Annual Reports and Statistics & $\mathrm{N}$ & $\mathrm{N}$ & $\mathrm{N}$ & $\mathrm{N}$ & $\mathrm{N}$ & $\mathrm{N}$ & $\mathrm{N}$ & $\mathrm{N}$ & $\mathrm{N}$ & $\mathrm{N}$ \\
\hline Ongoing projects & $\mathrm{N}$ & $\mathrm{N}$ & $\mathrm{Y}$ & $\mathrm{N}$ & $\mathrm{N}$ & $\mathrm{N}$ & $\mathrm{N}$ & $\mathrm{N}$ & $\mathrm{N}$ & $\mathrm{N}$ \\
\hline
\end{tabular}

\section{Key: $\mathrm{Y}=$ Yes, $\mathbf{N}=$ No}

Table 1 shows that only UNN library website have information about its parent institution. All library websites studied reported to have information about the library. UNIBEN, UNILAG, UI and UNIILORIN libraries failed 
to include mission/vision statements in their websites. Five of the library websites studied has information on working hours/holidays except UNN, ABU, UNIZIK, UNIILORIN library websites. Report on information about membership showed that all the library websites have membership information except UNN, UNIZIK and UNIILORIN library websites. Only ABU library website included information on copyright among the entire library websites studied. None of the libraries studied have information on library committee, ongoing projects or annual reports/statistics, similarly, all the library websites indicated to have information about sections/division of the library. UI, UNIZIK and UNAAB library websites reported to have information on their staff, in the same vein only UI and UNAAB library websites have information on site map/floor plan.

7.2 Physical Collection of the Library

Major physical collection of a university library includes books, journals, newspapers/magazines, reference materials, thesis/dissertations, conference proceedings, annual reports, government publications, publication of international, organisations/NGOs.

Table 3: Information about the Physical Collection of the Library

\begin{tabular}{|c|c|c|c|c|c|c|c|c|c|c|}
\hline Library Physical Collection & 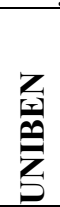 & $\underset{\mathrm{Z}}{\mathrm{Z}}$ & $\underset{Z}{Z}$ & 5 & 尝 & $\frac{2}{2}$ & $\begin{array}{l}\bar{\alpha} \\
\stackrel{\alpha}{0} \\
\underline{z}\end{array}$ & $\underset{\mathbf{N}}{\underline{\mathbf{S}}}$ & $\frac{\sum}{3}$ & $\begin{array}{l}\mathbf{Z} \\
\underline{\underline{\Xi}} \\
\underline{\mathbf{Z}} \\
\underline{\mathrm{Z}}\end{array}$ \\
\hline Books & $\mathrm{N}$ & $\mathrm{N}$ & $\mathrm{Y}$ & $\mathrm{Y}$ & $\mathrm{N}$ & $\mathrm{Y}$ & $\mathrm{Y}$ & $\mathrm{Y}$ & $\mathrm{Y}$ & $\mathrm{Y}$ \\
\hline Journals & $\mathrm{N}$ & $\mathrm{N}$ & $\mathrm{Y}$ & $\mathrm{Y}$ & $\mathrm{N}$ & $\mathrm{Y}$ & $\mathrm{N}$ & $\mathrm{N}$ & $\mathrm{Y}$ & $\mathrm{N}$ \\
\hline Newspapers/Magazines & $\mathrm{N}$ & $\mathrm{N}$ & $\mathrm{N}$ & $\mathrm{N}$ & $\mathrm{N}$ & $\mathrm{N}$ & $\mathrm{N}$ & $\mathrm{N}$ & $\mathrm{N}$ & $\mathrm{N}$ \\
\hline Reference Materials & $\mathrm{N}$ & $\mathrm{N}$ & $\mathrm{Y}$ & $\mathrm{N}$ & $\mathrm{N}$ & $\mathrm{N}$ & $\mathrm{N}$ & $\mathrm{N}$ & $\mathrm{N}$ & $\mathrm{N}$ \\
\hline Thesis/dissertations & $\mathrm{N}$ & $\mathrm{N}$ & $\mathrm{Y}$ & $\mathrm{N}$ & $\mathrm{N}$ & $\mathrm{N}$ & $\mathrm{N}$ & $\mathrm{N}$ & $\mathrm{N}$ & $\mathrm{N}$ \\
\hline Conference Proceedings & $\mathrm{N}$ & $\mathrm{N}$ & $\mathrm{N}$ & $\mathrm{N}$ & $\mathrm{N}$ & $\mathrm{N}$ & $\mathrm{N}$ & $\mathrm{N}$ & $\mathrm{N}$ & $\mathrm{N}$ \\
\hline Annual Reports & $\mathrm{N}$ & $\mathrm{N}$ & $\mathrm{N}$ & $\mathrm{N}$ & $\mathrm{N}$ & $\mathrm{N}$ & $\mathrm{N}$ & $\mathrm{N}$ & $\mathrm{N}$ & $\mathrm{N}$ \\
\hline Government Publications & $\mathrm{N}$ & $\mathrm{N}$ & $\mathrm{N}$ & $\mathrm{N}$ & $\mathrm{N}$ & $\mathrm{N}$ & $\mathrm{N}$ & $\mathrm{N}$ & $\mathrm{N}$ & $\mathrm{N}$ \\
\hline Publication of International Organisations/NGOs & $\mathrm{N}$ & $\mathrm{N}$ & $\mathrm{N}$ & $\mathrm{N}$ & $\mathrm{N}$ & $\mathrm{N}$ & $\mathrm{N}$ & $\mathrm{N}$ & $\mathrm{N}$ & $\mathrm{N}$ \\
\hline
\end{tabular}

\section{Key: $Y=$ Yes, $\mathbf{N}=$ No}

Table 2 revealed the information available on the library physical collection. It was revealed that only UNIBEN, UNILAG, and UNN library websites indicated to have information on book and journal holdings, only AUN library website reported to have information on reference materials and thesis/dissertation. None of the libraries websites have information on newspapers/magazines, conference proceedings, annual reports, government publications, publication of international, organisations/NGOs on their websites.

7.2 Library Services

Library service includes OPAC, reference desk/email/SMS/FAQ, circulation, CAS, SDI, ILL, indexing and abstracting, bibliographic services.

Table 4: Information about the Library Services

\begin{tabular}{|c|c|c|c|c|c|c|c|c|c|c|}
\hline Library Services & $\begin{array}{l}\text { Z } \\
\text { 量 } \\
\text { 号 }\end{array}$ & $\underset{\mathrm{Z}}{\stackrel{\mathrm{Z}}{\mathrm{Z}}}$ & 岂 & 5 & 㐏 & $\stackrel{\bullet}{2}$ & $\begin{array}{l}\underline{\alpha} \\
\underline{0} \\
\bar{z} \\
\bar{z}\end{array}$ & $\frac{\mathbf{v}}{\mathbf{Z}}$ & $\sum_{b}^{\infty}$ & 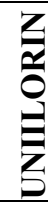 \\
\hline OPAC & $\mathrm{N}$ & $\mathrm{Y}$ & Y & $\mathrm{Y}$ & Y & $\mathrm{Y}$ & Y & $\mathrm{N}$ & $\mathrm{Y}$ & $\mathrm{Y}$ \\
\hline $\begin{array}{l}\text { Reference Desk/Email/SMS/FAQ/ } \\
\text { Feedback }\end{array}$ & $\mathrm{Y}$ & $\mathrm{Y}$ & $\mathrm{Y}$ & $\mathrm{Y}$ & $\mathrm{Y}$ & $\mathrm{Y}$ & $\mathrm{Y}$ & $\mathrm{Y}$ & $\mathrm{N}$ & $\mathrm{Y}$ \\
\hline Circulation & $\mathrm{N}$ & $\mathrm{N}$ & $\mathrm{Y}$ & $\mathrm{N}$ & $\mathrm{N}$ & $\mathrm{N}$ & $\mathrm{Y}$ & $\mathrm{N}$ & $\mathrm{N}$ & $\mathrm{N}$ \\
\hline CAS & $\mathrm{Y}$ & $\mathrm{Y}$ & $\mathrm{Y}$ & $\mathrm{Y}$ & $\mathrm{Y}$ & $\mathrm{Y}$ & $\mathrm{Y}$ & $\mathrm{Y}$ & $\mathrm{Y}$ & $\mathrm{Y}$ \\
\hline SDI & $\mathrm{N}$ & $\mathrm{N}$ & $\mathrm{Y}$ & $\mathrm{N}$ & $\mathrm{N}$ & $\mathrm{N}$ & $\mathrm{N}$ & $\mathrm{N}$ & $\mathrm{N}$ & $\mathrm{N}$ \\
\hline ILL & $\mathrm{N}$ & $\mathrm{N}$ & $\mathrm{N}$ & $\mathrm{Y}$ & $\mathrm{N}$ & $\mathrm{N}$ & $\mathrm{N}$ & $\mathrm{N}$ & $\mathrm{N}$ & $\mathrm{N}$ \\
\hline Indexing and Abstracting & $\mathrm{N}$ & $\mathrm{N}$ & $\mathrm{N}$ & $\mathrm{N}$ & $\mathrm{N}$ & $\mathrm{N}$ & $\mathrm{N}$ & $\mathrm{N}$ & $\mathrm{N}$ & $\mathrm{N}$ \\
\hline Bibliographic services & $\mathrm{N}$ & $\mathrm{N}$ & $\mathrm{N}$ & $\mathrm{N}$ & $\mathrm{N}$ & $\mathrm{N}$ & $\mathrm{N}$ & $\mathrm{N}$ & $\mathrm{N}$ & $\mathrm{N}$ \\
\hline
\end{tabular}

Key: $\mathrm{Y}=$ Yes, $\mathbf{N}=\mathbf{N o}$

Table 3 shows the information about the library services on the library websites. The table showed that all the library websites have OPAC except UINBEN and UNIZIK library websites. It further showed that only UNAAB library website lack reference desk/email/SMS/FAQ/feedback, similarly UNIPORT and AUN library websites reported to have on circulation while all the library websites have information on CAS. None of the library websites have information on SDI except AUN library and in the same vein none have information on ILL except UI library website. All the library websites indicated to have no information on indexing, abstracting and 
bibliographic services.

7.3 E-resource Holdings of the Libraries

Electronic resources represent an increasingly important component of the collection building activities of libraries. Inventory of electronic resources used for this study includes e-books, e-journals, e-database, CD/DVD ROMs, video cassettes, institutional repository, e- thesis/dissertation.

Table 4: Information about E-resource Holdings in the Libraries

\begin{tabular}{|c|c|c|c|c|c|c|c|c|c|c|}
\hline E-resources & $\begin{array}{l}\text { Z } \\
\text { 量 } \\
\text { 点 }\end{array}$ & $\underset{⿱ 乛}{\stackrel{Z}{Z}}$ & Z & 5 & 六 & 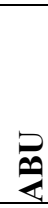 & 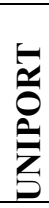 & $\frac{v}{\mathbf{Z}}$ & $\sum_{3}^{\infty}$ & 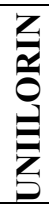 \\
\hline E-books & $\mathrm{Y}$ & $\mathrm{Y}$ & $\mathrm{Y}$ & $\mathrm{Y}$ & $\mathrm{N}$ & $\mathrm{N}$ & $\mathrm{N}$ & $\mathrm{Y}$ & $\mathrm{N}$ & $\mathrm{Y}$ \\
\hline E-journals & $\mathrm{Y}$ & $\mathrm{Y}$ & $\mathrm{Y}$ & $\mathrm{Y}$ & $\mathrm{N}$ & $\mathrm{N}$ & $\mathrm{N}$ & $\mathrm{Y}$ & $\mathrm{Y}$ & $\mathrm{Y}$ \\
\hline E-database & $\mathrm{Y}$ & $\mathrm{Y}$ & $\mathrm{Y}$ & $\mathrm{Y}$ & $\mathrm{Y}$ & $\mathrm{Y}$ & $\mathrm{Y}$ & $\mathrm{Y}$ & $\mathrm{Y}$ & $\mathrm{Y}$ \\
\hline CD/DVD ROMs & $\mathrm{N}$ & $\mathrm{N}$ & $\mathrm{Y}$ & $\mathrm{N}$ & $\mathrm{N}$ & $\mathrm{N}$ & $\mathrm{N}$ & $\mathrm{N}$ & $\mathrm{N}$ & $\mathrm{N}$ \\
\hline Video Cassettes & $\mathrm{N}$ & $\mathrm{N}$ & $\mathrm{N}$ & $\mathrm{N}$ & $\mathrm{N}$ & $\mathrm{N}$ & $\mathrm{N}$ & $\mathrm{N}$ & $\mathrm{N}$ & $\mathrm{N}$ \\
\hline Institutional Repository & $\mathrm{N}$ & $\mathrm{Y}$ & $\mathrm{Y}$ & $\mathrm{N}$ & $\mathrm{Y}$ & $\mathrm{Y}$ & $\mathrm{N}$ & $\mathrm{Y}$ & $\mathrm{N}$ & $\mathrm{N}$ \\
\hline E- thesis/dissertation & $\mathrm{N}$ & $\mathrm{Y}$ & $\mathrm{Y}$ & $\mathrm{Y}$ & $\mathrm{Y}$ & $\mathrm{Y}$ & $\mathrm{N}$ & $\mathrm{Y}$ & $\mathrm{N}$ & $\mathrm{N}$ \\
\hline
\end{tabular}

Key: $\mathrm{Y}=$ Yes, $\mathrm{N}=\mathrm{No}$

Table showed that UNIBEN, UNILAG, AUN, UI, UNIZIK and UNIILORIN library websites have information about their e-journals and e-book holdings except UNAAB library website which contain information only on ejournal holdings of the library while UNN, ABU, UNIPORT library websites neither have information on their e-journals or e-book holdings in their libraries. The entire library websites studied showed that they have information on e-databases. Only AUN library website reported to have information on CD/DVD ROMs holdings. None of the library websites studied has information on their video cassette holdings. UNIBEN, UI, UNIPORT and UNIILORIN reported to have no information on institutional repository while in a similar vein UNIBEN, UNIPORT UNAAB and UNIILORIN library websites lack information on their e-thesis/dissertation holdings.

7.4 Links to Free External E-resources

Links to free external e-resources is a key feature of any library website. Links used for this study includes national virtual library, e-journal directories, e-book directories, institutional repository directories, newspapers, search engines and courseware.

Table 5: Links to Free External E-resources

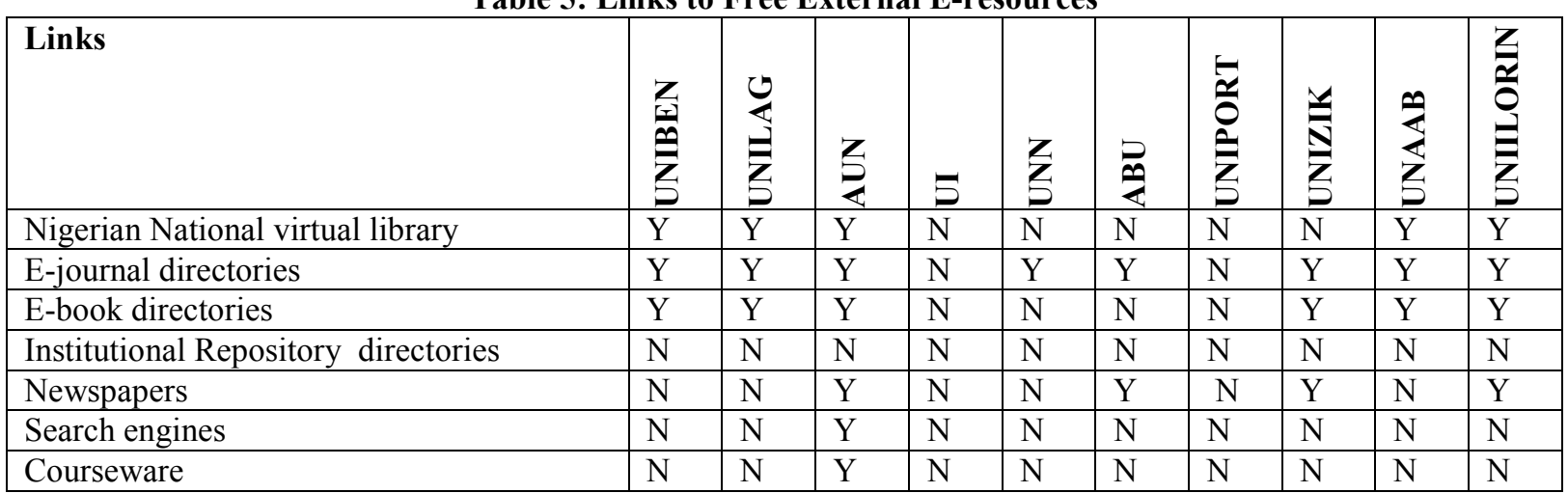

Key: $\mathrm{Y}=$ Yes, $\mathrm{N}=$ No

Table 5 shows the links to free external resources in the libraries. It is reported that UNIBEN, AUN, UNAAB and UNIILORIN included links to Nigerian national virtual library. Only UI and UNIPORT library websites failed to include links to directory of electronic journals, in same vein UI, UNN, ABU and UNIBEN also failed to include links to directory of e-books. None of the libraries studied have links to institutional repository directories. AUN, ABU, UNIZIK and UNILORIN provided links to newspapers. However, none of the library websites studied has links to search engines and courseware except AUN library website.

\section{Major Findings of the Study}

From the foregoing analysis, examination and interpretation of the data collected, the following major findings are reported by the researchers:

1. Only one out of the libraries studied gave information about its parent institution while majority failed to adequately give information about themselves on their websites by omitting completely important 
information like about their parent institution, library committee and annual report/statistics.

2. It also found in the study that the library websites did not give enough information on their physical collection by completely neglecting information about newspapers/magazines, conference proceedings, annual reports, government publications, publication of international organisations/NGOs.

3. The study clearly indicated that many of the library services are captured in the library websites studied except indexing and abstracting and bibliographic services.

4. The study discovered that the library websites studied have given adequate preference to their electronic resources except video cassettes which the researchers confirmed it may not be unconnected to its perceived old age technology and the presence of CD/DVD ROMs

5. Despite been free information resources, it is evident that none of the library websites gave a links to any of the directory of open access repositories. The findings also further revealed that only AUN library website included links to search engines and courseware. It is also indicated that very little preference was given to links to free e-resource directories that are begging to be exploited.

6. Lastly, the findings further revealed that AUN library website was rated the best in terms of content availability, this revelation affirmed AUN award as the 2013 ALA presidential citations for innovative international library projects.

\section{Conclusion and Recommendations}

The analysis of selected Nigeria university library websites features and content in comparison with international trends clearly indicates that library website development in Nigerian university libraries is in its infancy. These websites were often developed as a routine organisational matter instead of a conscious process of library promotion and marketing in an ever growing technology savvy user environment. Very few websites showed serious understanding by librarians of the worth of web technology and their professional involvement. Although the university library websites have made considerable presence of some major items on the checklist, there is enormous scope for improving the websites for enhanced visitation. In inference, it must be noted that a beautiful library without a well-developed library website is nothing but a moribund and an ineffective information system. Based on the findings of the study, following recommendations can improve the library websites in Nigerian universities:

1. Librarians should fully participate in development of their library websites for better accessibility, effective and efficient library website.

2. Seminars/workshops and conferences should be organised on interval basis for serving librarians on website development and evaluation to improve their skills.

3. Website design should be included in the library and information science curriculum in Nigerian library schools.

4. University library websites should focus attention to fulfill information seeking needs of users rather than emphasising administrative information about the library.

5. Directory of Nigerian university library website should be developed by National Universities Commission (NUC) for enhanced marketability and accessibility.

\section{References}

Akintunde, S.A. (2004), "Libraries as Tools for ICT Development", Paper Presented at the $42^{\text {nd }}$ Annual National Conference and AGM, NLA Makudi.

Brower, M.S. (2004), "Academic Health Sciences Library Website Navigation: An Analysis of Forty-one Websites and their Navigation tools", Journal of the Medical Library Association, 92(4) 412-20.

Davis, F.D. (1989), "Perceived Usefulness, Perceived Ease of Use and User Acceptance of Information Technology", MIS Quarterly, 13 (3), 319-40.

Diaz, K.R. (1998), "The Role of the Library Website: A Step Beyond Deli Sandwiches", Reference \& User Services Quarterly 38 (1): 41-43.

Huang, K., Lee, Y. and Wang, R. (1999), "Quality Information and Knowledge”, Prentice-Hall, Englewood Cliffs, NJ.

Kumar, M. (2009), "Academic Libraries in Electronic Environment: Paradigm Shift", A paper presented at the International Conference on Academic Libraries (ICAL) held at the University of Delhi, India. P. 105

Lee, K.H. (2001), "Evaluation of Academic Library Websites in Malaysia", Malaysian Journal of Library and Information Science, (2), 95-108.

Lilili, K. (2009), "Emerging Technologies for Academic Libraries in Digital Age”, Oxford: Chandos: 24.

Michalec, M., (2006). "A Content Analysis of Art Library Websites", Art Documentation, 25(2), $46-54$.

Nielsen, J. and Tahir, M. (2002), "Homepage Usability: 50 Websites Deconstructed”, New Riders, Indianapolis, IN.

Okiy, R.B. (2005), "Funding Nigerian Libraries in the 21st Century: Will Funding from Alternative Sources 
Suffice? The Bottom Line", Managing Library Finances, 18(2), 71-77.

Singh, J. and Kaur, T. (2009), "Future of Academic Libraries in India: Challenges and Opportunities", A paper Presented at the International Conference on Academic Libraries (ICAL) held at the University of Delhi, India. Vaughan, J, (2001), "Three Iterations of an Academic Library Website", Information Technology and Libraries, 20 (2), 81-92.

Ward, J. and Mervar, D. (2003), "Beyond the Web: Promoting the Value of a Library's Websites", Florida Libraries, 46(2), 15-17.

Abubakar Mohammed holds Bachelor of Library Science (BLS) from University of Maiduguri and currently a student of MSc Information Science in Ahmadu Bello University Zaria, he is member of Nigerian Library Association (NLA) and Certified Librarian of Nigeria (CLN) his area of research interest includes: electronic resource management, computers in libraries, local content management and digital libraries.

Aminu Garba is a Senior Librarian with Hussaini Adamu Federal Polytechnic Kazaure, he holds Bachelor of Library and Information Science (BLIS) from Ahmadu Bello University Zaria and currently a student of MSc Information Science in same University, he is member of Nigerian Library Association (NLA) and Certified Librarian of Nigeria (CLN) his area of research interest includes: electronic document delivery system, ICTs in libraries, electronic reference services and digital interlibrary relations.

Hafiz Umar is a Librarian I with Federal Polytechnic Bali, he holds Bachelor of Library and Information Science (BLIS) from Ahmadu Bello University Zaria and currently a student of Masters in Archives and Record Management (MARM) in same University, he is member of Nigerian Library Association (NLA) and Certified Librarian of Nigeria (CLN) his area of research interest includes: electronic records management system, digitisation in libraries and public records management. 